International Journal of Current Microbiology and Applied Sciences

ISSN: 2319-7706 Volume 10 Number 02 (2021)

Journal homepage: http://www.ijcmas.com

\title{
Multiple Impact of National Watershed Project in Low Rainfall Region: A Case Study from Prakasam District, Andhra Pradesh
}

\author{
PVRM. Reddy ${ }^{1}$, M. Girija Shankar ${ }^{1}$, N. Polappa ${ }^{1}$, Y. Shankar Naik ${ }^{1}$, \\ B. Swati ${ }^{*}$, L. Sudhakara Reddy ${ }^{2}$ and G. Prabhaker ${ }^{2}$ \\ ${ }^{1}$ Department, Govt. of Andhra Pradesh, PVS ICON, Beside Reliance Digitals, \\ Tadepalli Village, Guntur District, India \\ ${ }^{2}$ NABARD Consultancy Services Pvt. Ltd (Wholly Owned Subsidiary of NABARD),Zonal \\ Office for Andhra Pradesh and Telangana, NABARD Building, Musheerabad, \\ Hyderabad, India
}

*Corresponding author

\section{A B S T R A C T}

\section{Keywords}

\section{Geographic} Information System, Normalized Difference Vegetation Index,

Normalized Difference Water Index, National Remote Sensing Centre, Mahatma Gandhi National Rural Employment Guarantee Scheme

Article Info

Accepted:

14 January 2021

Available Online:

10 February 2021
Vaggampalli Pradhan Mantri Krishi Sinchayee Yojana (PMKSY) watershed project was implemented from 2011-2018 with treatable area of 4644 hectares covering four micro watersheds. This paper discuss the impact of watershed interventions on bio-physical, hydrological, agricultural and socio-economic indicators. Changes were detected in land use for agriculture crops, water body coverage and area under very good soil moisture. Ground water table and crop productivity were improved. Migration of workers from rural to urban areas was declined.The mean gross income of households was increased. Overall, the watershed interventions provided resilience by ensuring sustainable multiple outputs, besides soil and water conservation.

\section{Introduction}

The rain fed areas of prakasam district are characterized by low rainfall and its erratic distribution, frequent droughts, depleted water resources, degraded soils with uncertain agricultural production and limited resources of farmers and landless poor (Prabhakar 
Pathak et al., 2013). In consideration of these ground conditions, the department of Rural Development, Government of Andhra Pradesh has been implementing PMKSY Watershed Development Component (erstwhile IWMP) in a phased manner, since 2009-10. In the present multiple impact assessment, new technologies of remote sensing and Geo-graphic Information System (GIS) were used for bio-physical indicators. Remote sensing for data acquisition on the earth resource, whereas GIS is used for data analysis (Meenakshi Bai $\mathrm{R}$ et al., 2018). Integrated Management of Watershed Program interventions have positive impacts on various bio-physical aspects such as investment on soil and water conservation measures, expansion in cropped area, changes in cropping pattern, production and productivity of crops (Palanisami K et al., 2009). The main objective of the impact study related to bio-physical (land use land cover, vegetation cover, soil moisture), hydrological (ground and surface water), agricultural and allied (crop and livestock productivity, cropping pattern), and socio-economic (employment in agriculture and nonagriculture activities, migration from rural to urban areas, wage structure, drinking water and household incomes) indicators to assess the benefits accrued in terms of sustainable agriculture and livelihoods, restoration of ecological balance, better access to drinking water and endurable overall development of stakeholders in the watershed area.

Study area: The Vaggampalli mega watershed project of PMKSY sanctioned for 2011-12 was implemented by Andhra Pradesh Government in Pamur mandal, Prakasam district with treatable area of 4644 hectares encompassing 4 Micro Watersheds with a fund allocation of 557.28 lakhs. The project is completed after 7 years of implementation in 3 (preparatory, work and consolidation) phases. The total geographical area of the watershed is 7254 hectares. Vaggampalli is located between the latitudes $\mathrm{N} 15^{\circ} 10^{\prime} 32^{\prime \prime}$ to longitude E $79^{\circ} 27^{\prime} 39^{\prime \prime}$ at ridge point and between latitude $\mathrm{N} 15^{\circ} 09^{\prime} 55^{\prime \prime}$ to longitude $\mathrm{E}$ $79^{\circ} 27^{\prime} 19$ at valley point. The study area has majorly plain area. The major streams and other $1^{\text {st }}, 2^{\text {nd }}$ and higher order streams are draining in the watershed area.

The location map of Vaggampalli watershed project is shown in Fig.1

\section{Materials and Methods}

\section{Bio-physical indicators}

The bio-physical indicators such as land use and land cover, normalized difference vegetation index (NDVI) and normalized difference water index (NDWI) indices are studied using remote sensing and GIS techniques. Satellite imagery of LISS IV (5.8 $\mathrm{m}$ resolution) are procured from NRSC Portal for image interpretation (Vani V et al., 2017). ERDAS Imagine and ArcGIS software was used to prepare the final maps. Date of satellite pass is 05 October 2012 for pre project period and 14 September 2018 for post project period.

Land Use and Land Cover Classification and Mapping: The satellite data covered 100 per cent of the project area. Land use land cover classification was carried out using onscreen visual interpretation techniques in GIS environment. The classified images having different land use land cover categories pertaining to pre and post treatment period were compared to derive information on changes. Ground truth undertaken in conjunction with the use of multi-resolution remote sensing data to assess the changes in land use with the implementation of watershed programme (Venkata Shashank K et al., 2020). 


\section{Normalized Difference Vegetation Index}

Normalized Difference Vegetation Index (NDVI) was computed using the Infrared and Red bands of satellite data:

$\mathrm{NDVI}=(\mathrm{IR}-\mathrm{R}) /(\mathrm{IR}+\mathrm{R})$

The maps generated based on NDVI are used to describe vegetation dynamics and monitor the seasonal growing conditions for making primary productivity analysis (Vani $\mathrm{V}$ et al., 2018).

\section{Normalized Difference Water Index}

Normalized Difference Water Index (NDWI), a satellite-derived index from the NearInfrared (NIR) and Short-Wave Infrared (SWIR) channels, was used for remote sensing of vegetation liquid water from space. NDWI is sensitive to changes in liquid water content of vegetation canopies:

$\mathrm{NDWI}=(\mathrm{NIR}-\mathrm{SWIR}) /(\mathrm{NIR}+\mathrm{SWIR})$

NDWI value was calculated for maximum soil moisture in comparatively deep soils and minimum value (-1) for dry lands i.e. rocky, sandy or barren. Remote Sensing images for NDWI values in wet soils appear darker than dry surfaces.

\section{Hydrological and Agricultural Indicators}

The study cover hydrological indicators such as water resources (ground water, rainfall and irrigation), natural resources management (soil \& moisture conservation, rain water harvesting, afforestation), and agricultural indicators such as crop and animal productivity. The depth of water to ground level $(\mathrm{bgl}, \mathrm{m})$ in the project area, total annual rainfall $(\mathrm{mm})$ and deviation from normal during the project period are considered in this study. Accomplishment of category wise natural resource management works and activities with the funds of IWMP and MGNREGS for development of water resources and crop productivity in the watershed project are detailed. The irrigation, crop and milch cattle details are collected in household survey and Focus Group Discussion (FGD) during field visit.

\section{Socio-economic indicators}

The field study was conducted in September thru November months of 2019 as per the tool designed for the Household Survey and Focus Group Discussion.The Socio economic indicators viz; employment, migration from rural to urban areas, wage structure, drinking water supply and household income were studied for impact assessment of watershed interventions. The gross returns per annum of households based on size of land holding of beneficiary farmers from farming, dairying and wage labour is calculated.

Sample selection: Sample Households were randomly selected from watershed community including OC, BC, SC, ST, and minorities, women headed households, landless households, marginal, small and big farmers representing all hamlets/villages in each micro watershed.

Sample size: The household survey covered $100 \%$ of mega project area with five per cent of total Households in each micro watershed. Out of $1518 \mathrm{HHs}$ in the project, a total of 76 HHs (5\%) are selected.

Data collection: Structured schedules developed were used to collect Household data as per the sample size in each micro watershed duly following the sample selection criteria. The investigators have visited each micro watershed of IWMP project to survey Households. The field investigators during the visits have organized Focus Group Discussion 
involving various stakeholders of watershed community. Secondary data were collected in personal interviews and interactions with the watershed committee, Project Iimplementing Aagency and District Water Management Agency at district level. The information related to pre project period is captured from Detailed Project Report (DPR).

\section{Results and Discussion}

The present study is focused mainly on biophysical, hydrological, agricultural and socioeconomic impacts of different interventions of watershed project.

\section{Bio-physical impacts}

Watershed developmental activities have made significant positive impacts on various biophysical aspects. $^{7}$

\section{Land use land cover}

Land use and land cover changes as observed from satellite imagery of LISS IV data for the year 2012 (pre project period) and 2018 (post project period) are provided in Table 1 and Fig.2a \& b. Comparison of pre and post implementation satellite imagery is the most common remote sensing approach used for impact evaluation (Kumar G et al., 2014). The study results show that land use for agriculture crops increased by 16.7 per cent from 2488.5 ha to 2903.1 ha, including forage crops; agriculture Plantations area decreased by 67.9 per cent, in spite of plantations in 82 hectares and horticultural crops in 62 hectares during project period. Combined together of decline in plantations and forest areas, the vegetation cover in the project area decreased by 657 ha. Area of water body coverage increased by 18.2 per cent. Change detection of spatio-temporal land use land cover help for optimum resource planning and utilization for sustainable development (Anurag et al., 2018).

\section{Vegetation Cover}

The spatial and temporal changes in vegetation cover are presented in Table 2 . Compared to the Pre-project period, the dense vegetation cover decreased by 434 ha and the open vegetation cover by 2166 ha at the end of project period. Adoption of soil and water conservation practices had not helped in development of dense and open vegetation, while sparse vegetation increased by 527.9 per cent (2607 ha).

Changes in Vegetation cover measured in pre and post project period through Normalized Difference Vegetation Index (NDVI) are represented in Fig.3a \& b. NDVI is the suitable index for measuring changes in vegetation cover. ${ }^{9}$ the extent of cropped area or phenoregions was assessed by NDVI (Miura T et al., 2006).

\section{Soil moisture}

Soil moisture availability through wetness indicators was assessed by Normalized Difference Water Index (NDWI). NDWI is sensitive to changes in liquid water content of vegetation canopies. Based on computed NDWI as shown in Table 3 and Fig.4a\&b, there was change in soil moisture of the watershed areas as a result of the watershed activities. The area under very good soil moisture increased by 178.3 per cent from 641.39 ha in pre project period to 1785.21 ha of watershed area at the end of project period; the area under medium soil moisture increased by 113.8 per cent from 1124.63 to 2404.53 ha, while the area under less soil moisture declined by 79.4 per cent.

\section{Hydrological and agricultural impacts}

\section{Natural Resource Management}

Natural Resource Management (NRM) is the major thrust area of watershed program for 
the works such as land development, soil moisture conservation, water harvesting structures and afforestation etc.,. The details of physical and financial achievements under NRM component are detailed in Table 4. In all, two hundred twelve works under Integrated Water Management Program (IWMP) are executed with an expenditure of 311.85 lakhs, which is 56.0 per cent of the project cost (IWMP AP MIS R.2.1 (A) 2020). Beside, 824 works are executed under MGNREGS with an expenditure of 116.58 lakhs. Effective management of natural resources (soil, water and vegetation) supported by other interventions of watershed project resulted in increased cultivation of agriculture and horticultural crops with enhanced productivity per unit area.

\section{Water resources}

Rainfall: The rainfall (actual and normal) data given in Fig. 5 for the project areas show that there was deficit rainfall in six of the eight years of project implementation period (IMD, 2020). The deficit rainfall was recorded in four successive years from 2011 to 2014. The per cent deviation of actual rainfall in these four years varied from as low as 20.8 in 2011 to 162.7 in 2014 . More than normal was received in $2015(16.3 \%)$ and $2017(7.5 \%)$.

Ground water: The depth of water availability in tube wells in both the pre and post project periods considered and noticed that there is rise in the average depth of water table in the tube wells to the extent of $2.5 \mathrm{~m}$ in post project period. Deepening of tube wells in some areas are affecting the water quality.

Irrigation: Implementation of the watershed program in the selected project has resulted in increase of irrigated areas at the end of project period by $18.4 \%$ from 206 to 244 ha.
Conservation of soil moisture and recharging of ground water and rainwater harvesting measures (Table-4), helped in rise of the ground water table, in spite of less rainfall in several years during project period. Added to this, there is increase in farmer's awareness on better water management practices, growing water efficient crops, and short duration crop varieties.

\section{Crops and cropping pattern}

Crop yield: The per hectare economic yield of the major crops in the post project period was higher due to growing of high yielding crop varieties, adoption of recommended package of practices, effectively conserving and utilizing the soil moisture and rainfall. Beside, higher crop productivity was supported through Production System Intervention (PSI) activities to establish custom hire centers, provide implements and high cost farm machinery to individual farmers, and supply micro-irrigation system and water carrying pipes at a cost of 46.0 lakhs. In respect of individual crops, the productivity of cereal crops increased by 3.2 to $12.4 \%$, pulses by 2.9 to $10.7 \%$, vegetables by 4.5 to $10.6 \%$, fruit crops by 3.9 to $7.6 \%$, plantation crops by 6.5 to $8.3 \%$ (Table 5) during the project period.

\section{Cropping pattern}

In the post project period, ccereals (paddy and millet's) and pulse crops were the predominant crops in the watershed area constituting more than $80.0 \%$ of the cultivated area. Vegetables including chilies constituted $7.3 \%$ and fruit crops $2.9 \%$. The area under plantation crops like subabul and eucalyptus constituted $1.9 \%$ of the area.The cropping pattern did not change much between pre and project periods, except in area of these crops on year to year. In post project period, the area under paddy declined 
from 9.5 to $4.9 \%$, plantation crops from 3.5 to $1.9 \%$ and pulses from 57.9 to $50.4 \%$ (Fig.6). However, the area under horticultural crops (vegetables and fruit crops) increased from 4.3 to 10.2 per cent.

\section{Livestock}

Milch Cattle, Milk Production and Productivity: The number of milch cattle increased in the project period by 52.4 per cent from 836 to 1274 as income generating activity for landless poor, marginal and small farmers in the watershed project. Under the livelihood component of the project, buffaloes were supplied to 75 beneficiaries belonging to SC (62), ST (4), and BC (9) categories by incurring 25.31 lakhs. As part of production system improvement (PSI) component of the project, nutritional support was given to pregnant milch animals during last 100 days of pregnancy, and to calves at a cost of Rs.1.2 lakhs. The total milk production per year increased by 101.1 per cent from 673.6 to 1354.6 KL/yr. with increase of milk productivity by $32.5 \%$ from 4.0 to $5.3 \mathrm{l} /$ day in the watershed project. The farmers who own milch cattle have secured income to meet the family expenditure, even during drought years.

Small ruminants: Under livelihood component of the project, a total of 49 small ruminants such as goats and goat children are supplied at a total cost of Rs. 21.9 lakhs to beneficiaries of social categories i.e. schedule caste (13), schedule tribe (4), backward class (13), minority (4) and other category (15). In convergence mode with animal husbandry department, twenty four small ruminant health camps were organized during the period at a cost of Rs.1.5 lakhs.

Table.1 Satellite Imagery based Land Use/ Land Cover details

\begin{tabular}{|c|c|c|c|c|c|c|}
\hline \multirow{2}{*}{$\begin{array}{c}\text { Land Use/Land Cover } \\
\text { Class }\end{array}$} & \multicolumn{2}{|c|}{ Pre Project } & \multicolumn{2}{c|}{ Post Project } & \multicolumn{2}{c|}{ Change } \\
\cline { 2 - 7 } & Area, ha & $\%$ & Area, ha & $\%$ & Area, ha & $\%$ \\
\hline Built up Land & 30.01 & 0.6 & 42.73 & 0.9 & 12.72 & 42.4 \\
\hline Agriculture-Crop Land & 2488.51 & 51.7 & 2903.11 & 60.3 & 414.6 & 16.7 \\
\hline $\begin{array}{c}\text { Vegetation } \\
\text { (Agro Plantation) }\end{array}$ & 817.52 & 17.0 & 262.52 & 5.5 & $(-\mathrm{ve}) 555$ & $(-\mathrm{ve}) 67.9$ \\
\hline Forest & 484.87 & 10.1 & 383.05 & 8.0 & $($-ve) 102 & $(-\mathrm{ve}) 21.0$ \\
\hline Waste Land & 869.66 & 18.1 & 1152.01 & 23.9 & 282 & 32.5 \\
\hline Water body & 56.92 & 1.2 & 67.29 & 1.4 & 10 & 18.2 \\
\hline Cloud & 65.36 & 1.4 & 2.04 & 0.0 & $(-\mathrm{ve}) 63$ & $(-\mathrm{ve}) 96.9$ \\
\hline Total & 4812.75 & 100.0 & 4812.75 & 100.0 & & \\
\hline
\end{tabular}

Table.2 Change in Vegetation Cover during the project period

\begin{tabular}{|l|c|c|c|c|c|c|}
\hline \multirow{2}{*}{ Vegetation Cover Type } & \multicolumn{2}{|c|}{ Pre project } & \multicolumn{2}{c|}{ Post project } & \multicolumn{2}{c|}{ Change } \\
\cline { 2 - 8 } & Area, ha & $\%$ & Area, ha & $\%$ & Area, ha & $\%$ \\
\hline Dense Vegetation & 503.63 & 10.5 & 70.06 & 1.5 & $(-\mathrm{ve}) 434$ & $(-\mathrm{ve}) 86.1$ \\
\hline Open Vegetation & 3807.55 & 79.1 & 1641.67 & 34.1 & $(-\mathrm{ve}) 2166$ & $(-\mathrm{ve}) 56.9$ \\
\hline Sparse Vegetation & 493.82 & 10.3 & 3100.75 & 64.4 & 2607 & 527.9 \\
\hline Built up, Barren land & 7.75 & 0.2 & 0.27 & 0.0 & $(-\mathrm{ve}) 7$ & $(-\mathrm{ve}) 96.5$ \\
\hline Total & 4812.75 & 100.0 & 4812.75 & 100.0 & & \\
\hline
\end{tabular}


Table.3 Change in soil moisture during the project period

\begin{tabular}{|l|l|l|l|l|l|l|}
\hline \multirow{2}{*}{ Soil Moisture Type } & Pre project & \multicolumn{3}{l|}{ Post project } & \multicolumn{2}{l|}{ Change } \\
\cline { 2 - 8 } & Area, ha & $\%$ & Area, ha & $\%$ & Area, ha & $\%$ \\
\hline Good Soil Moisture & 641.39 & 13.33 & 1785.21 & 37.09 & 1143.82 & 178.3 \\
\hline Medium Soil Moisture & 1124.63 & 23.37 & 2404.53 & 49.96 & 1279.9 & 113.8 \\
\hline $\begin{array}{l}\text { Less Soil Moisture } \\
\text { Water Spread Area \& } \\
\text { Cloud }\end{array}$ & 23.22 & 0.48 & 0.58 & 0.01 & 22.74 & 97.9 \\
\hline TOTAL & 4812.75 & 100 & 4812.75 & 100 & 4812.75 & 100 \\
\hline
\end{tabular}

Table.4 NRM Category Wise Physical and Financial Achievements

\begin{tabular}{|c|c|c|c|c|c|c|}
\hline \multirow[t]{2}{*}{ Name of the Activity } & \multicolumn{2}{|c|}{ IWMP } & \multicolumn{2}{|c|}{ MGNREGS } & \multicolumn{2}{|c|}{ Total } \\
\hline & $\begin{array}{l}\text { Physical } \\
\text { (No.) }\end{array}$ & $\begin{array}{l}\text { Financial } \\
\text { (L) }\end{array}$ & $\begin{array}{l}\text { Physical } \\
\text { (No.) }\end{array}$ & $\begin{array}{l}\text { Financi } \\
\text { al (L) }\end{array}$ & $\begin{array}{l}\text { Physical } \\
\text { (No.) }\end{array}$ & $\begin{array}{c}\text { Financia } \\
1(\mathrm{~L})\end{array}$ \\
\hline Land development works & 10 & 9.2 & 175 & 15.7 & 185 & 24.9 \\
\hline Soil moisture conservation works & 11 & 9.0 & 19 & 3.9 & 30 & 12.9 \\
\hline Water harvesting structures & 141 & 278.6 & 530 & 61.3 & 671 & 339.9 \\
\hline Repairs to existing whs & 2 & 3.8 & 7 & 2.9 & 9 & 6.7 \\
\hline Afforestation works & 42 & 10.4 & 56 & 13.6 & 98 & 24.0 \\
\hline Horticulture works & 0 & 0.0 & 37 & 19.1 & 37 & 19.1 \\
\hline Livestock related works & 6 & 0.8 & 0 & 0.0 & 6 & 0.8 \\
\hline $\begin{array}{l}\text { Total no. of NRM works \& } \\
\text { expenditure }\end{array}$ & 212 & 311.9 & 824 & 116.6 & 1036 & 428.4 \\
\hline Total project area (ha) & \multicolumn{6}{|c|}{4644} \\
\hline Total project cost (Rs. in lakhs) & \multicolumn{6}{|c|}{557.28} \\
\hline$\%$ of NRM expenditure & \multicolumn{6}{|c|}{56.0} \\
\hline
\end{tabular}

Table.5 Crop Yields in Pre and Post project Period

\begin{tabular}{|c|c|c|c|c|}
\hline \multirow{2}{*}{ Name of Crop } & Unit & & Crop yield, ha & \\
\cline { 3 - 5 } & & Pre & Post & Change\% \\
\hline Paddy & Quintals & 52.4 & 54.1 & 3.2 \\
\hline Jowar & Quintals & 10.5 & 11.8 & 12.4 \\
\hline Red gram & Quintals & 10.2 & 10.5 & 2.9 \\
\hline Chillies (Red) & Quintals & 26.9 & 28.1 & 4.5 \\
\hline Subabul & Quintals & 35.1 & 37.4 & 6.5 \\
\hline Eucalyptus & Quintals & 30 & 32.5 & 8.3 \\
\hline Mango & Tons & 17.1 & 18.4 & 7.6 \\
\hline Papaya & Tons & 38.5 & 40 & 3.9 \\
\hline Acid Lime & Tons & 20.9 & 22 & 5.3 \\
\hline Tomato & Tons & 18 & 19.9 & 10.6 \\
\hline Brinjal & Tons & 21.2 & 22.6 & 6.6 \\
\hline Bengal Gram & Quintals & 12.1 & 13.4 & 10.7 \\
\hline
\end{tabular}


Fig.1 Location Map of Vaggampalli PMKSY watershed project
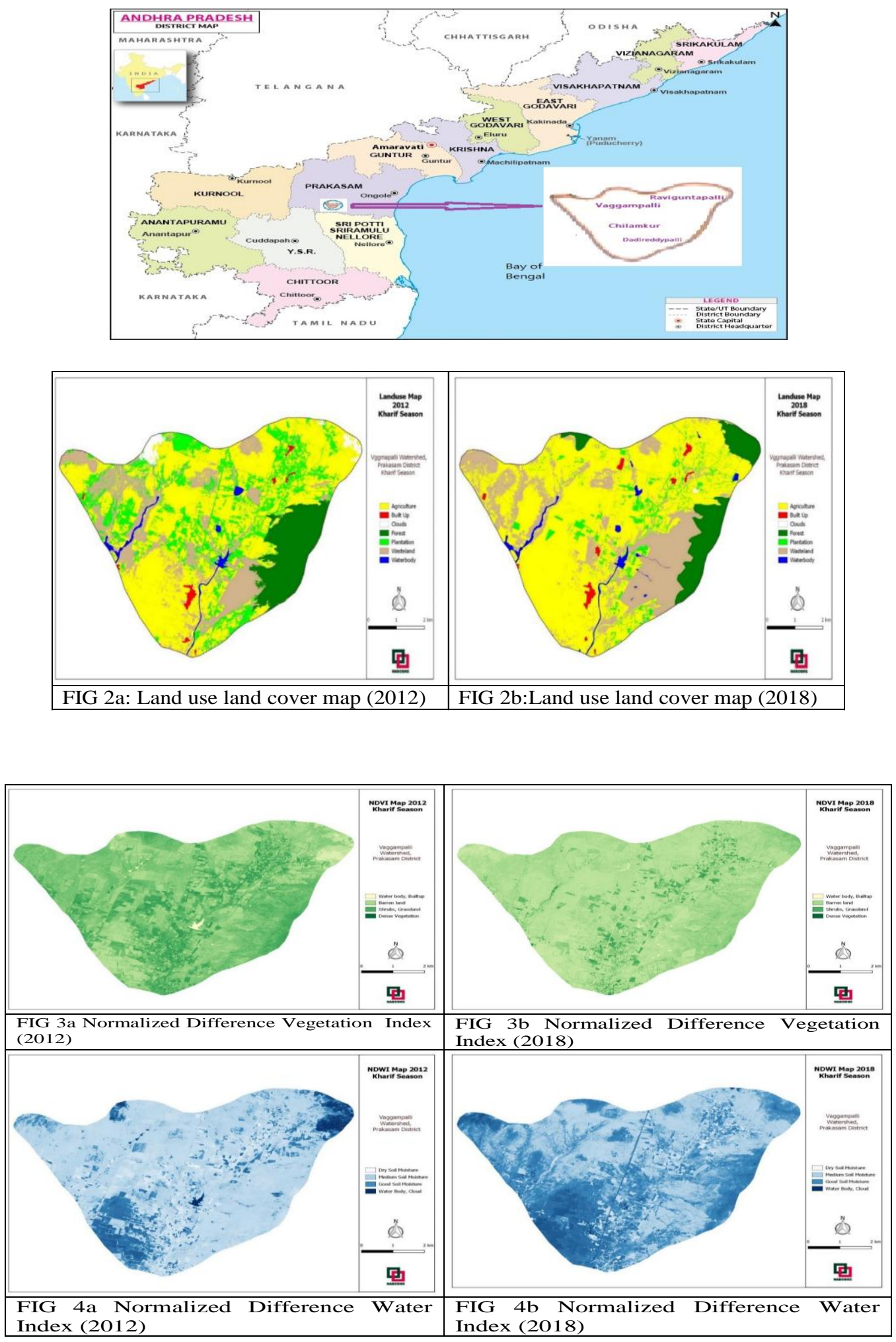
Fig.5 Annual Rainfall during the project period

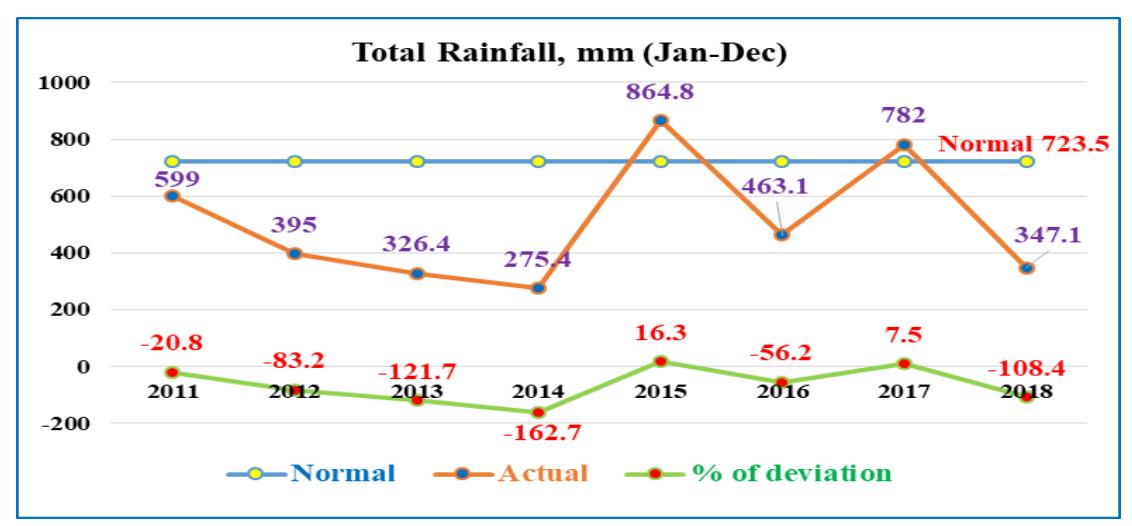

Fig.6 Cropping Pattern (\%)

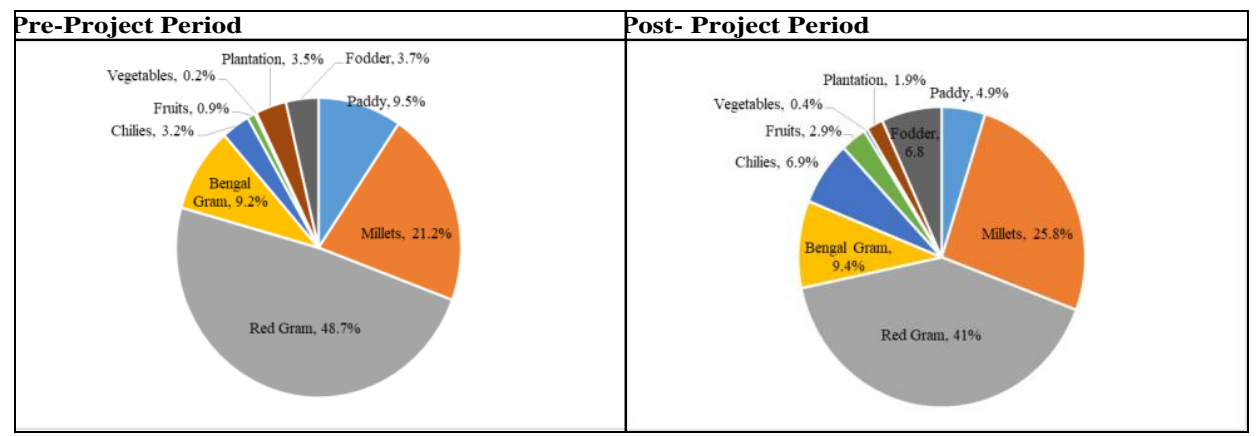

Fig.7 Gross returns based on size of land holding, Rs./Yr/HH

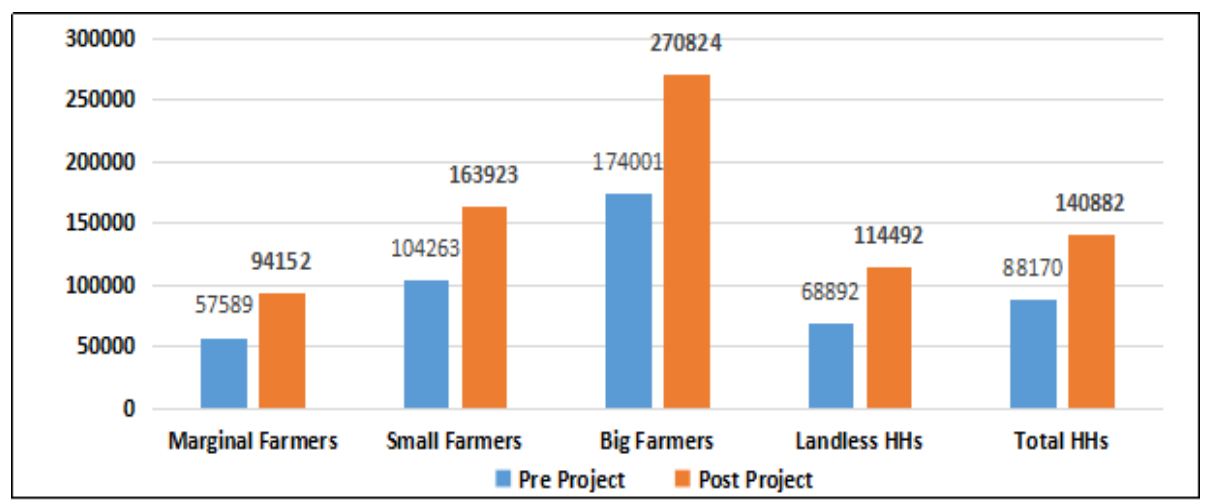

\section{Socio-economic impacts}

\section{Employment and Wage Structure}

Employment: Number of person days/yr/family in agriculture and nonagriculture related activities during project implementation period increased by $31.0 \%$ (33 person days) and $17.2 \%$ (25 person days), respectively. The impact of watershed interventions was observed in enhancement of employment opportunities in agriculture and non-agriculture employment due to increased agricultural activities, NRM works, PSI 
support activities, convergence of MGNREGA and other line departments/schemes. In all, 61,496 man days were generated for 1482 wage seekers including 416 from schedule caste and 63 from schedule tribes, during the project period. Overall, the migration of workers from rural to urban areas declined by $60 \%$ reducing the number from 140 to 56 at the end of project period.

Wage structure: Wage earnings increased on an average by Rs.87 per day for men from Rs. 275 to Rs.362, and Rs.35 per day for women from Rs.155 to Rs. 190 during the project period. In lean months, the persons were engaged in NRM and MGNREGS works, where they received more wages compared to agricultural operations.

\section{Drinking water}

The drinking water supplies improved by $27.5 \%$ in post project period from 19,520 to 24,890 1/day due to watershed interventions such as creation of new water sources, installation of R.O. plants, laying of water supply pipes, which is adequate to meet the requirement of the population.

\section{Gross Income of Households}

The mean gross income of households increased by 59.8 per cent from Rs. 88,170 to Rs. $1,40,882$ at the end of project period. The gross income based on size of land holding of beneficiary farmers are presented in Fig.7. The annual household's income of marginal farmers after the project period is Rs.94, 152, which is 63.5 per cent higher of the preproject period. The annual gross income of small farmers increased by 57.2 per cent over the pre-project period raising to Rs.1,63,923 and the gross income of large landholders increased by 55.6 per cent over the preproject period reaching Rs.2,70,824. The annual gross income of landless households from subsidiary activities like rearing of milch animals and wage income from agriculture and non-agricultural activities increased to Rs.1, 14,492 in the post-project period showing an increase of 59.8 per cent.

In Conclusion the impacts of watershed management interventions were observed in increase of cultivation area by $16 \%$ especially horticultural crops, expansion of water bodies, better soil moisture in the profile.The water resources improved through soil and water conservation measures, groundwater recharge and harvesting of rain water. Higher crop and milk yields, increase in employment and wage rates helped in reduction of migration and higher income to households in the watershed project. These positive outcomes on successful implementation of the watershed program were translated into sustainable livelihoods. The impact of watershed interventions in ground water recharges and overall growth of agricultural production would have been greater, but for six deficit rainfall years.

\section{Acknowledgements}

NABARD Consultancy Services (P) Ltd (NABCONS), a wholly owned subsidiary of NABARD, as MEL\&D Agency for PMKSY Watershed Projects in cluster III (Prakasam and Guntur) of Andhra Pradesh has conducted the final impact evaluation study of Vaggampalli watershed project. The study is funded by the Commissioner, Panchayat Raj \& Rural Development and Chief Executive Officer, State Level Nodal Agency, Government of Andhra Pradesh. Our sincere thanks to the Commissioner, PR\&RD and CEO, SLNA, Government of AP, Vijayawada and the Director (WS) for the permission accorded to access the secondary data available at SLNA web site (iwmp.ap.gov.in). 


\section{References}

Anurag, Ankita Saxena and Biswajeet Pradhan. 2018, Land Use/Land Cover Change Modelling: Issues and Challenges. Journal of Rural development, 37, No. 2, 413-424.

Indian Meteorological Department (IMD). 2020. Customized Rainfall Information System (CRIS), Hydromet Division, Ministry of Earth Sciences, New Delhi.

(http://hydro.imd.gov.in/hydrometweb/(S(abw y3n45bw3mbj55rryeh2e5))/DistrictRaif all.aspx)

IWMP AP MIS. R.2.1 (A). 2020. NRM category wise report, Management Information System, Integrated Watershed Management Programme, Andhra Pradesh. (http://www.iwmp.ap.gov.in/WebRepor ts/UI/Works/NRM_category_new.aspx)

Kumar G, D.R.Sena, R.S.Kurothe, V.C.Pande, B.K.Rao, A.K.Vishwakarma, G.L.Bagdi and P.K.Mishra. 2014. Watershed impact evaluation using Remote Sensing. Current Science, 106, 10, 1369-1374.

Meenakshi Bai.R, R.Raghavendra and V.Rajesh. 2018. Application of Remote Sensing and GIS Techniques in Watershed Management.Res J. Chem. Environ. Sci., 6, 5 1-4.

Miura T., Huete, A., and Yoshioka, H. 2006. An empirical investigation of crosssensor relationships of NDVI and $\mathrm{read} / \mathrm{near}$ red-infrared reflectance using
EO-I Hyperion data. Remote Sensing of Environment, 100, 2, 223-236.

Palanisami K and Suresh Kumar D. 2009. Impacts of watershed Development Programmes: Experiences and Evidences from Tamil Nadu. Agricultural Economics Research Review, 22, 387- 396.

Prabhakar Pathak, Anil Kumar Chourasia, Suhas P. Wani, Raghavendra Sudi. 2013. Multiple Impact of Integrated Watershed Management in Low Rainfall Semi-Arid Region: A Case Study from Eastern Rajasthan, India. Journal of Water Resource and Protection, 5, 1.

Vani V and Mandla V R. 2017. Comparative study of NDVI and SAVI vegetation indices in Anatapur district semi-arid areas. International Journal of Civil Engineering and Technology, 8, 4, 559566.

Vani V and Pavan Kumar K. 2018. Crop condition assessment of groundnut using time series NDVI data in Anantapur district, Andhra Pradesh. Journal of Rural development, 37, 2, $167-178$.

Venkata Shashank Konduri, Jitendra Kumar, William W. Hargroved, Forrest M. Hoffman, Auroop R. Ganguly. 2020. Mapping crops within the growing season across the United States. Remote Sensing of Environment, 251, 112048.

\section{How to cite this article:}

Reddy, PVRM., M. Girija Shankar, N. Polappa, Y. Shankar Naik, B. Swati, L. Sudhakara Reddy and Prabhaker, G. 2021. Multiple Impact of National Watershed Project in Low Rainfall Region: A Case Study from Prakasam District, Andhra Pradesh. Int.J.Curr.Microbiol.App.Sci. 10(02): 377-387. doi: https://doi.org/10.20546/ijcmas.2021.1002.044 